Jurnal Ilmu Ilmu Agribisnis: Journal of Agribusiness Science, 9(3), Agustus 2021

\title{
POLA KONSUMSI DAN PERMINTAAN BERAS TINGKAT RUMAH TANGGA DI KOTA BANDAR LAMPUNG
}

\author{
(Consumption Pattern and Household Demand on Rice in Bandar Lampung City) \\ Ican Aido, Fembriarti Erry Prasmatiwi, Rabiatul Adawiyah
}

\begin{abstract}
Jurusan Agribisnis, Fakultas Pertanian, Universitas Lampung, Jl. Prof. Dr. Soemantri Brodjonegoro No. 1 Bandar Lampung 35145, e-mail: fembriarti.erry@fp.unila.ac.id
\end{abstract}

\begin{abstract}
This research aims to examine the pattern of rice consumption, rice demand and the factors that influence household rice demand in Bandar Lampung City. This study used a survey method involving 64 respondents chosen randomly and consisted of 32 respondents from Panjang District and 32 respondents from by Sukarame District. Data collection was carried out in November to December 2018 and analyzed qualitatively, statistically descriptive and verification using multiple linear regression. The results showed that the pattern of household rice consumption in Bandar Lampung City consisted of the types of rice consumed by households was random rice, IR 64, Pandan Wangi, and Rojolele with the type of rice most consumed by households was IR 64. The quality of rice consumed by households was super rice. Most of the households consume rice because of habits. Total household rice consumption was 15-25 $\mathrm{kg}$ per month. The majority of households consume 3 times per day. The total household rice demand in Bandar Lampung City was $25.31 \mathrm{~kg}$ per month and the average demand per capita was $6.33 \mathrm{~kg}$ per month. Factors affecting household rice demand in Bandar Lampung City were the price of bread, the price of chicken, and the number of household members.
\end{abstract}

Key words: consumption pattern, demand, rice

\section{PENDAHULUAN}

Beras merupakan makanan pokok bagi sebagian besar masyarakat Indonesia. Konsumsi beras di Indonesia semakin meningkat setiap tahunnya seiring dengan meningkatnya jumlah penduduk Indonesia. Ketergantungan masyarakat Indonesia yang sangat tinggi terhadap beras akan menjadi masalah, jika ketersediaan beras sudah tidak dapat tercukupi. Berdasarkan BPS (2017), total konsumsi beras Indonesia tahun 2017 mencapai sekitar 29,13 juta ton atau $111,58 \mathrm{~kg} / \mathrm{kapita} / \mathrm{tahun}$. Konsumsi beras tersebut tidak hanya digunakan untuk rumah tangga, tapi juga untuk hotel, restoran, rumah makan, industri, jasa kesehatan, maupun jasa lainnya. Lebih lanjut BPS (2017) menyatakan bahwa konsumsi beras nasional yang terbesar adalah rumah tangga yaitu sebesar 21,32 juta ton atau 73,14 persen dari total konsumsi beras nasional. Tingginya konsumsi beras rumah tangga karena beras merupakan pangan pokok yang setiap saat harus dapat dipenuhi. Menurut Hessie (2009), pangan pokok adalah pangan yang muncul dalam menu sehari-hari, mengambil porsi terbesar dalam hidangan dan merupakan sumber energi terbesar. Tingginya konsumsi beras sebagai pangan pokok tergambar pada struktur pengeluaran rumah tangga yaitu pengeluaran pangan terbesar digunakan untuk beras (Prasmatiwi, Listiana, dan Rosanti 2014).

Kota Bandar Lampung merupakan ibukota Provinsi Lampung. Menurut BPS Provinsi Lampung (2017), kebutuhan konsumsi beras Kota Bandar Lampung sebesar 72.373 ton dengan asumsi konsumsi per kapita adalah 92,78 $\mathrm{kg} / \mathrm{kap} / \mathrm{th}$. Menurut Imelda (2016), konsumsi dipengaruhi oleh dua faktor, yaitu faktor internal dan faktor eksternal. Faktor internal misalnya jumlah anggota keluarga, pendapatan, pendidikan, preferensi, dan pengetahuan gizi. Faktor eksternal meliputi agroekologi, produksi, ketersediaan, distribusi, dan promosi. Menurut hasil penelitian Bangun, Hutajalu, dan Salmiah (2013), konsumsi beras rumah tangga dipengaruhi oleh jumlah anggota keluarga dan tingkat pendapatan.

Jumlah beras yang dikonsumsi berkaitan erat dengan kemampuan rumah tangga dalam membeli dan memperoleh beras tersebut. Jumlah beras yang dikonsumsi rumah tangga dapat menggambarkan permintaan beras tingkat rumah tangga. Jenis beras yang dikonsumsi akan menentukan pola konsumsi rumah tangga. Berdasarkan uraian tersebut, maka tujuan penelitian ini yaitu untuk mengkaji pola konsumsi beras rumah tangga, 
permintaan rumah tangga terhadap beras dan faktor-faktor yang mempengaruhi permintaan beras rumah tangga di Kota Bandar Lampung.

\section{METODE PENELITIAN}

Metode yang digunakan dalam penelitian ini adalah metode survei. Lokasi penelitian dipilih secara sampling bertahap. Rumah tangga kelas bawah diwakili oleh kecamatan yang memiliki jumlah rumah tangga terbanyak yang berada pada kelompok prasejahtera. Rumah tangga kelas atas diwakili oleh kecamatan yang memiliki jumlah rumah tangga terbanyak yang berada pada kelompok sejahtera III+. Lokasi kelurahan dipilih berdasarkan pertimbangan jumlah rumah tangga terbanyak. Terpilih Kelurahan Panjang Selatan dan Kelurahan Way Dadi Baru. Waktu pengumpulan data dilakukan pada bulan November-Desember 2018. Penentuan jumlah sampel mengacu pada Sugiarto (2001) dengan rumus:

$\mathrm{n}=\frac{\mathrm{NZ} \mathrm{S}^{2}}{\mathrm{Nd}^{2}+\mathrm{Z}^{2} \mathrm{~s}^{2}}$

Keterangan:

n = Jumlah sampel

$\mathrm{N} \quad=$ Jumlah populasi (25.700 orang)

$\mathrm{S}^{2} \quad=$ Varian sampel $(5 \%)$

$\mathrm{Z} \quad=$ Tingkat kepercayaan $(90 \%=1,645)$

d $\quad=$ Derajat penyimpangan $(5 \%=0,05)$

$\mathrm{n}=\frac{25.700 \times 1,645^{2} \times 0,05^{2}}{25.700 \times 0,05^{2}+1,645^{2} \times 0,05^{2}}$

$\mathrm{n}=64,25$ atau 64 rumah tangga.

Berdasarkan jumlah populasi di dua kelurahan yang ada di Kecamatan Panjang dan Kecamatan Sukarame Kota Bandar Lampung berjumlah 25.700 orang. Dari perhitungan di atas diperoleh sebanyak 64 rumah tangga di Kota Bandar Lampung yang akan dijadikan responden.

Jenis data yang digunakan adalah data primer dan data sekunder. Data primer merupakan data yang dikumpulkan melalui wawancara secara langsung terhadap konsumen menggunakan kuesioner. Data primer diperoleh dengan cara wawancara langsung dengan responden berdasarkan daftar pertanyaan (kuesioner) yang telah dipersiapkan. Kuesioner adalah suatu daftar yang berisikan rangkaian pertanyaan mengenai sesuatu masalah atau bidang yang akan diteliti (Ariesman, Prasmatiwi, dan
Indriani 2015). Data sekunder diperoleh dari instansi-instansi yang terkait. Metode analisis data yang digunakan dalam penelitian adalah metode analisis kualitatif, statistik deskriptif dan verifikatif dengan menggunakan regresi linier berganda. Analisis pola konsumsi beras dilakukan secara deskriptif dengan cara mendeskripsikan pola konsumsi beras rumah tangga, yang meliputi jenis beras yang dibeli oleh rumah tangga, frekuensi pembelian (konsumsi), dan jumlah konsumsi.

Jumlah konsumsi suatu komoditi menggambarkan jumlah permintaan terhadap komoditi tersebut. Menurut Nopirin (1994), faktor yang berpengaruh terhadap permintaan adalah harga komoditi itu sendiri, pendapatan, selera, perkiraan (ekspektasi), jumlah konsumen, dan harga barang lain. Dalam penelitian ini yang mendeskripsikan pengaruh pola konsumsi beras rumah tangga adalah harga beras, harga mie instant, harga roti, harga telur, harga tempe, harga ayam, harga ikan, tingkat pendapatan, dan jumlah anggota rumah tangga.

Dalam menganalisis faktor-faktor yang mempengaruhi permintaan beras. digunakan model regresi berupa fungsi perpangkatan. Faktor-faktor yang diduga mempengaruhi permintaan beras adalah harga beras (X1), harga mie instant (X2), harga roti (X3), harga telur (X4), harga tempe (X5), harga ayam (X6), harga ikan (X7), tingkat pendapatan (X8), jumlah anggota rumah tangga (X9). Persamaannya adalah sebagai berikut.

$$
\begin{aligned}
& \mathrm{Y}=\mathrm{b} 0 \mathrm{X} 1^{\mathrm{b} 1} \mathrm{X} 2^{\mathrm{b} 2} \mathrm{X} 3^{\mathrm{b}} \mathrm{X} 4^{\mathrm{b} 4} \times 5^{\mathrm{b} 5} \mathrm{X} 6^{\mathrm{b} 6} \mathrm{X} 7^{\mathrm{b} 7} \mathrm{X} 8^{\mathrm{b} 8} \\
& X 9^{\mathrm{b} 9} \mathrm{e}^{\mathrm{u}}
\end{aligned}
$$

Untuk menduga parameter model, maka fungsi persamaan (3) tersebut ditransformasikan ke dalam bentuk logaritma natural (ln), sehingga diperoleh persamaan regresi linier berganda sebagai:

$$
\begin{aligned}
\mathrm{LnY}= & \operatorname{lnb} 0+\mathrm{b} 1 \ln \mathrm{X} 1+\mathrm{b} 2 \ln \mathrm{X} 2+\mathrm{b} 3 \ln \mathrm{X} 3+\mathrm{b} 4 \ln \mathrm{X} 4 \\
& +\mathrm{b} 5 \ln \mathrm{X} 5+\mathrm{b} 6 \ln \mathrm{X} 6+\mathrm{b} 7 \ln \mathrm{X} 7+\mathrm{b} 8 \ln \mathrm{X} 8+ \\
& \mathrm{b} 9 \ln \mathrm{X} 9+\mathrm{U} \ldots \ldots \ldots \ldots \ldots \ldots \ldots \ldots \ldots \ldots \ldots \ldots \ldots \ldots \ldots \ldots \ldots \ldots \ldots \ldots \ldots \ldots \ldots
\end{aligned}
$$

di mana:

$\mathrm{Y} \quad=$ Permintaan beras $(\mathrm{kg} / \mathrm{bulan})$

b0 = Intersep

b1-b9 = Koefisien variabel bebas

$\mathrm{X} 1=$ Harga beras $(\mathrm{Rp} / \mathrm{kg})$

$\mathrm{X} 2=$ Harga mie instant $(\mathrm{Rp} / 100$ gram $)$

$\mathrm{X} 3=$ Harga roti $(\mathrm{Rp} / 100 \mathrm{gr})$

$\mathrm{X} 4=$ Harga telur $(\mathrm{Rp} / 100 \mathrm{gr})$

$\mathrm{X} 5=$ Harga tempe $(\mathrm{Rp} / 100 \mathrm{gr})$

$\mathrm{X} 6$ = Harga ayam $(\mathrm{Rp} / 100 \mathrm{gr})$

$\mathrm{X} 7 \quad=$ Harga ikan $(\mathrm{Rp} / 100 \mathrm{gr})$

$\mathrm{X} 8=$ Tingkat pendapatan ( Rp/bulan)

$\mathrm{X} 9=$ Jumlah anggota rumah tangga (jiwa)

$\mathrm{u} \quad=$ Kesalahan acak 
Tabel 1. Sebaran rumah tangga menurut kualitas, jenis beras, dan frekuensi konsumsi beras rumah tangga di Kota Bandar Lampung.

\begin{tabular}{lcc}
\hline Pola Konsumsi & $\begin{array}{c}\text { Jumlah Rumah } \\
\text { Tangga }\end{array}$ & $\begin{array}{c}\text { Persentase } \\
(\%)\end{array}$ \\
\hline 1. Kualitas beras & & \\
- Asalan & 10 & 15,63 \\
- Super & 54 & 84,37 \\
2. Jenis beras & & \\
- Asalan & 10 & 15,63 \\
- IR 64 & 41 & 64,06 \\
- IR 64 dan Pandan & & \\
Wangi & 12 & 18,75 \\
- IR 64 dan Rojo Lele & 1 & 1,56 \\
3. Frekuensi konsumsi & & \\
- 2 kali/hari & 18 & 28,12 \\
- 3 kali/hari & 37 & 57,81 \\
- 4 kali/hari & 9 & 14,06 \\
\hline
\end{tabular}

Hasil data yang telah diolah diuji menggunakan Uji F dan Uji t. Pengujian regresi secara serempak menggunakan Uji $\mathrm{F}$ untuk mengetahui apakah semua variabel bebas ( $\left.\mathrm{X}_{1}-\mathrm{X}_{9}\right)$ secara bersamasama berpengaruh nyata terhadap variabel terikat (Y1). Pengujian secara tunggal dengan Uji t bertujuan untuk mengetahui apakah semua variabel bebas $\left(\mathrm{X}_{1}-\mathrm{X}_{9}\right)$, secara tunggal berpengaruh nyata terhadap variabel terikat (Y1). Untuk menguji hasil regresi, agar tidak menghasilkan persamaan yang bias, maka dilakukan uji asumsi klasik (Ghozali 2006).

Uji multikolinearitas dapat diketahui dengan melihat nilai VIF. Jika nilai $\mathrm{VIF}<10$, maka tidak terjadi multikolinearitas. Jika nilai $\mathrm{P}$ value chi square < 5 persen, maka terdapat gejala heteroskedastisitas atau dapat diketahui dengan kaidah jika Prob $\mathrm{Obs}^{*} R$ square < 0,05 maka ada heteroskedastisitas, sedangkan jika Prob $\mathrm{Obs}^{*} R$ square $>0,05$ maka tidak ada heteroskedastisitas.

\section{HASIL DAN PEMBAHASAN}

Hasil penelitian menunjukkan bahwa usia responden konsumen beras tingkat rumah tangga di Kota Bandar Lampung berkisar 24-55 tahun dengan rata-rata 37 tahun. Mayoritas tingkat pendidikan responden adalah tamat Sekolah Menengah Atas (SMA) yaitu sebanyak 56 orang $(87,50 \%)$. Mayoritas pekerjaan responden adalah ibu rumah tangga yaitu 50,00 persen dan sebesar 28,00 persen adalah wiraswasta dan sisanya adalah pegawai swasta, PNS, dan karyawan. Jumlah anggota rumah tangga berkisar 2 sampai 5 orang dan terbanyak $(51,56 \%)$ berkisar antara empat sampai lima orang. Rata-rata pendapatan rumah tangga sebesar Rp5.636.172 per bulan.

\section{Pola Konsumsi Beras Rumah Tangga di Kota Bandar Lampung}

Pola konsumsi pangan memberikan informasi mengenai jenis pangan, jumlah, dan frekuensi pangan setiap hari (Santoso 2004). Pola konsumsi beras rumah tangga di Kota Bandar Lampung menginformasikan tentang jenis beras yang dikonsumsi, frekuensi mengkonsumsi, dan jumlah yang dikonsumsi. Jenis beras yang dikonsumsi dan frekuensi konsumsi rumah tangga di Kota Bandar Lampung disajikan pada Tabel 1.

\section{Jenis Beras}

Berdasarkan kualitas beras yang dikonsumsi rumah tangga di Kota Bandar Lampung adalah beras kualitas super yaitu 84,37 persen dan sisanya 15,63 persen kualitas asalan. Beras asalan adalah beras yang dinilai kualitasnya lebih rendah, baik dari bentuk maupun rasa. Biasanya beras asalan dijual dengan harga lebih murah, beras patah (broken) lebih 10 persen, kadang ditemukan kotoran atau gabah, dan dijual curah atau tidak dalam bentuk kemasan, beras super adalah beras yang memiliki kualitas tinggi, warna beras jauh lebih putih atau bersih, berbau harum, dan memiliki rasa yang khas, kadar pecah 0-10 persen serta tidak ditemukan kotoran. Jenis beras yang dikonsumsi rumah tangga di Kota Bandar Lampung mayoritas adalah beras jenis IR64, selain itu Pandan Wangi dan Rojolele. Untuk beras asalan biasanya jenisnya campuran bermacam-macam.

\section{Frekuensi Konsumsi Beras Per Hari di Kota Bandar Lampung}

Frekuensi konsumsi beras adalah frekuensi mengkonsumsi beras atau nasi berapa kali masing-masing rumah tangga dalam satu hari. Berdasarkan Tabel 1, mayoritas frekuensi konsumsi beras per hari pada responden rumah tangga di Kota Bandar Lampung adalah tiga kali per hari yaitu sebanyak 37 rumah tangga $(57,81 \%)$ yaitu untuk makan pagi, siang, dan malam.

Tabel 2. Jumlah beras yang dikonsumsi per hari oleh rumah tangga di Kota Bandar Lampung (gram/hari)

\begin{tabular}{ccc}
\hline $\begin{array}{c}\text { Jumlah Konsumsi Beras } \\
\text { (gram/hari) }\end{array}$ & Jumlah RT & $\begin{array}{c}\text { Persentase } \\
(\%)\end{array}$ \\
\hline $500-833$ & 38 & 59,37 \\
$834-1.167$ & 19 & 29,68 \\
$1.168-1.500$ & 7 & 10,94 \\
\hline Jumlah & 64 & 100,00 \\
\hline
\end{tabular}


Uniknya ditemukan rumah tangga yang mempunyai kebiasaan makan 4 kali per hari yaitu sebesar 14,06 persen.

Dalam mengkonsumsi beras, setiap rumah tangga memiliki alasan tertentu yaitu karena alasan kebiasaan dan karena alasan kesehatan. Mayoritas responden rumah tangga menyatakan bahwa alasan mengkonsumsi beras adalah karena kebiasaan sejak kecil yang sudah diturunkan dari orang tua yaitu sebesar 90,63 persen.

\section{Jumlah Konsumsi Beras Per Hari}

Jumlah beras yang dikonsumsi rumah tangga per hari berkisar antara 500 gram sampai 1.500 gram dengan rata-rata 834,38 gram per hari atau 25.310 .25 gram $(25,31 \mathrm{~kg})$ per bulan. Jika dihitung jumlah konsumsi beras per kapita adalah sebesar $229,13 \mathrm{gram} / \mathrm{kapita} / \mathrm{hari}$ atau $6,33 \mathrm{~kg} / \mathrm{kapita} / \mathrm{bulan}$. Jumlah ini lebih rendah dibandingkan konsumsi beras di Lampung Tengah (Prasmatiwi et al. 2014) yaitu $8,14 \mathrm{~kg} / \mathrm{kapita} / \mathrm{bulan}$.

\section{Cara Mengkonsumsi Beras}

Dalam memasak beras, tidak ditemukan responden yang memasak beras secara manual atau tradisional menggunakan panci, dandang, atau kukusan dan mengolah beras di kompor. Seluruh responden rumah tangga di Bandar Lampung memasak beras dengan menggunakan magic com. Dengan menggunakan magic com pengolahan menjadi lebih praktis dan tidak membutuhkan tenaga yang banyak.

Selain mengkonsumsi nasi, ditemukan 93,75 persen responden mengkonsumsi mie instant. Uniknya ada responden yang mengkonsumsinya mie instant sebagai lauk untuk makan nasi, namun juga ada yang mengonsumsi sebagai pengganti nasi. Mie instant sangat mudah didapatkan dan diolah dengan harga yang terjangkau, di samping itu mengandung karbohidrat yang tinggi.

Tabel 3. Jenis, jumlah dan harga barang pelengkap atau lauk pauk yang dikonsumsi rumah tangga di Kota Bandar Lampung

\begin{tabular}{lccc}
\hline $\begin{array}{c}\text { Jenis } \\
\text { lauk }\end{array}$ & $\begin{array}{c}\text { Jumlah RT yang } \\
\text { mengkonsumsi }(\%)\end{array}$ & $\begin{array}{c}\text { Jumlah } \\
\text { Konsumsi } \\
(\mathrm{gr}) / \mathrm{bln}\end{array}$ & $\begin{array}{c}\text { Harga } \\
\text { Rp/100gr }\end{array}$ \\
\hline Telur & 93,75 & 5.031 & 2.250 \\
Ayam & 68,75 & 2.984 & 2.470 \\
Ikan & 59,37 & 4.593 & 2.800 \\
Tempe & 82,81 & 4.339 & 135 \\
\hline
\end{tabular}

Frekuensi konsumsi mie instant per bulan antara 4 sampai 15 kali per bulan dengan rata-rata 7 kali per bulan, Selain mie, ditemukan 59,38 persen responden mengonsumsi roti sebagai pengganti nasi terutama dikonsumsi untuk sarapan atau makan pagi. Jenis roti mayoritas adalah roti tawar disusul roti isi. Frekuensi mengonsumsi roti $0-4$ kali/bulan dengan rata-rata $3 \mathrm{kali} / \mathrm{bulan}$ dan jumlah konsumsi roti tiap rumah tangga adalah 760 gram/bulan.

Sebagai lauk untuk makan nasi yang paling banyak dikonsumsi oleh rumah tangga di Kota Bandar Lampung yaitu telur, ayam, ikan, dan tempe. Telur menjadi lauk yang paling favorit dikonsumsi yaitu dikonsumsi 93,75 persen rumah tangga. Tempe menjadi makanan kedua paling banyak dikonsumsi setelah telur yaitu sebesar 82,10 persen rumah tangga mengkonsumsi tempe, Sebesar 68,75 persen rumah tangga mengkonsumsi ayam dan 59,37 persen rumah tangga mengkonsumsi ikan.

\section{Faktor-Faktor yang Memengaruhi Permintaan Beras Tingkat Rumah Tangga di Kota Bandar Lampung}

Dalam penelitian ini yang dimaksud dengan permintaan beras adalah jumlah beras yang dibeli dan dikonsumsi oleh rumah tangga di Kota Bandar Lampung. Rata-rata permintaan beras rumah tangga di Bandar Lampung adalah 25,31 kg/bulan atau $6,33 \mathrm{~kg} / \mathrm{kapita} / \mathrm{bulan}$. Diduga faktor-faktor yang berpengaruh terhadap permintaan beras tingkat rumah tangga di Bandar Lampung adalah harga beras, harga mie instant, harga roti, harga telur, harga tempe, harga ayam, harga ikan, jumlah anggota keluarga, dan pendapatan.

Hasil analisis model terbaik faktor-faktor yang memengaruhi harga beras disajikan pada Tabel 5 . Koefisien determinasi (R2) pada persamaan tersebut adalah 0,7268 . Nilai tersebut menyatakan bahwa sebesar 72,68 persen variasi permintaan beras dapat dijelaskan oleh variasi variabel independen harga beras, harga mie instant, harga roti, harga telur, harga tempe, harga ayam, harga ikan, pendapatan, jumlah anggota rumah tangga. Sisanya (sebesar 27,32\%) dapat dijelaskan oleh variabel lain yang tidak dimasukkan ke dalam model yang diuji pada penelitian ini.

Nilai $\mathrm{F}$ hitung pada penelitian ini adalah 15,9646 dengan nilai signifikansi sebesar 0,0000. Hal tersebut berarti bahwa variabel harga beras, harga mie instant, harga roti, harga telur, harga tempe, 
Tabel 4. Hasil regresi linier berganda faktor-faktor yang memengaruhi konsumsi beras rumah tangga di Bandar Lampung, tahun 2019

\begin{tabular}{lrrrrc}
\hline \multicolumn{1}{c}{ Variable } & Coefficient & Std. Error & \multicolumn{1}{c}{ t-Statistic } & \multicolumn{1}{c}{ Prob. } & VIF \\
\hline Harga Beras (X1) & 0,229044 & 0,286051 & 0,800712 & 0,4268 & 1.416126 \\
Harga Mie Instant (X2) & $-0,037475$ & 0,191088 & $-0,196114$ & 0,8453 & 1.208608 \\
Harga Roti (X3) & $-0,168184^{* * *}$ & 0,028285 & $-5,946044$ & 0,0000 & 1.171053 \\
Harga Telur (X4) & $-0,533451$ & 0,479700 & $-1,112050$ & 0,2710 & 1.178435 \\
Harga Tempe (X5) & $-0,058503$ & 0,066361 & $-0,881582$ & 0,3819 & 1.217673 \\
Harga Ayam (X6) & $-0,719957 * * *$ & 0,220412 & $-3,266418$ & 0,0019 & 1.305263 \\
Harga Ikan (X7) & $-0,173061$ & 0,146423 & $-1,181927$ & 0,2424 & 1.412165 \\
Pendapatan (X8) & 0,010289 & 0,059191 & 0,173821 & 0,8627 & 1.747438 \\
Jumlah Anggota RT (X9) & $1,045167 * * *$ & 0,126204 & 8,281589 & 0,0000 & 1.318054 \\
C & 20,36111 & 4,552802 & 4,472215 & 0,0000 & \\
\hline
\end{tabular}

F hitung 15,96460

$R$-square $\quad 0,726833$

Adjusted $R$-square $\quad 0,681305$

Durbin-Watson stat $\quad 1,942526$

Keterangan : *** = Nyata pada tingkat kepercayaan $99 \%$

harga ayam, harga ikan, pendapatan, jumlah anggota rumah tangga secara bersama-sama nyata berpengaruh terhadap jumlah permintaan beras rumah tangga dengan tingkat kepercayaan 99 persen.

Untuk menguji hasil regresi agar tidak menghasilkan persamaan yang bias, maka dilakukan uji asumsi klasik Uji asumsi klasik tersebut meliputi uji multikolinieritas dan heteroskedastisitas (Ghozali 2006). Berdasarkan hasil uji asumsi klasik multikolinearitas, persamaan (Tabel 4) sudah terbebas dari masalah multikolinearitas. Hal ini ditunjukkan nilai VIF yang kurang dari 10. Hasil uji heteroskedastisitas menggunakan uji White dengan program eviews 10 nilai Prob $\mathrm{Obs}^{*} R$ square $>0,05$ yaitu sebesar 0,0517 yang artinya persamaan tidak terjadi heteroskedastisitas.

Berdasarkan hasil uji secara tunggal atau uji t, variabel bebas yang berpengaruh nyata terhadap permintaan beras tingkat rumah tangga di Bandar Lampung adalah harga roti (X3), harga ayam (X6) dan jumlah anggota rumah tangga (X9). Variabel yang tidak berpengaruh nyata terhadap permintaan beras adalah harga beras (X1), harga mie instant (X2), harga Telur (X4), harga tempe (X5), harga ikan (X7), dan pendapatan (X8).

\section{Harga Beras}

Harga beras tidak berpengaruh nyata terhadap permintaan beras. Pada Tabel 5 dapat dilihat bahwa nilai $\mathrm{t}$ hitung adalah 0,8007 dan probabilitasnya 0,4268 . Hal ini dapat dipahami karena beras merupakan kebutuhan pokok bagi rumah tangga di Bandar Lampung. Jika harga beras naik, maka rumah tangga tidak akan mengurangi beras tapi akan mengganti beras dengan kualitas yang lebih rendah. Harga beras yang dibeli konsumen di Bandar Lampung sangat bervariasi dan ada perbedaan yang tinggi antara beras kualitas asalan dengan beras kualitas super. Harga beras yang paling murah adalah jenis asalan yaitu sebesar Rp8.700,00/kg, diikuti jenis IR 64 yaitu sebesar Rp10.700,00/kg, pandan wangi Rp11.000,00/kg dan yang paling mahal adalah jenis Rojo lele yaitu sebesar Rp12.000,00/kg. Hasil penelitian sejalan dengan penelitian Hendaris, Zakaria, dan Kasymir (2013) bahwa harga beras tidak berpengaruh terhadap permintaan beras, namun berbeda dengan penelitian Harianto dan Susilo (2009) dan Prasmatiwi et al. (2014) bahwa harga beras berpengaruh negatif terhadap permintaan beras yang artinya semakin tinggi harga beras, maka permintaan beras semakin kecil.

\section{Harga Roti dan Harga Ayam}

Harga roti berpengaruh nyata negatif terhadap jumlah permintaan beras dengan tingkat kepercayaan 99 persen dan koefisien regresi sebesar $-0,1681$ yang artinya setiap terjadi kenaikan harga roti 1 persen, maka jumlah permintaan beras akan berkurang sebesar 0,1681 persen. Berdasarkan teori permintaan seharusnya koefisien harga roti bernilai positif bahwa jika harga roti meningkat sebesar 1 rupiah, maka akan meningkatkan permintaan beras 0,1681 persen. Harga ayam berpengaruh nyata terhadap jumlah permintaan beras dengan tingkat kepercayaan 99 persen. Nilai koefisien variabel harga ayam 
bernilai negatif yaitu sebesar -0,7199. Hal ini berarti jika harga ayam naik 1 persen, maka permintaan beras turun 0,7199 persen. Dengan demikian, ayam merupakan barang komplementer yang dimakan sebagai lauk. Hasil penelitian ini sejalan dengan Prasmatiwi et al. (2014).

\section{Jumlah Anggota Rumah Tangga}

Jumlah anggota rumah tangga berpengaruh nyata terhadap jumlah konsumsi beras dengan tingkat kepercayaan 99 persen. Nilai koefisien variabel jumlah anggota rumah tangga bernilai positif yaitu sebesar 1,0451. Hal ini berarti setiap kenaikan jumlah anggota keluarga sebesar 1 persen, maka jumlah permintaan beras akan naik sebesar 1,0451 persen. Hasil penelitian ini sejalan dengan penelitian pada protein hewani oleh Azhar, Zakaria, dan Adawiyah (2019), dimana semakin banyak jumlah anggota keluarga, maka jumlah tahu yang dikonsumsi lebih banyak.

\section{Harga Telur, Harga Ikan, Harga Tempe, dan Pendapatan}

Keempat variabel harga telur, harga ikan, harga tempe, dan tingkat pendapatan tidak berpengaruh nyata terdapat permintaan beras rumah tangga di Kota Bandar Lampung. Hal ini berarti dengan adanya perubahan harga telur, ikan, tempe, dan pendapatan, maka permintaan beras tidak berubah. Hal ini dapat dijelaskan bahwa tempe, ikan, telur merupakan lauk yang hampir tiap hari tersedia untuk menu sehari-hari. Jika harga ikan naik, rumah tangga akan mengganti jenis ikan yang harganya lebih murah. Begitu juga dengan pendapatan tidak berpengaruh terhadap permintaan beras, karena beras merupakan kebutuhan pokok bagi rumah tangga di Bandar Lampung. Hasil ini sejalan dengan penelitian Prasmatiwi et al. (2014) bahwa permintaan beras tidak dipengaruhi secara nyata oleh harga ikan, harga telur, dan harga tempe dan Deviana, Kusrini, dan Suyatno (2014) yang menyatakan pendapatan rumah tangga tidak berpengaruh nyata terhadap permintaan beras.

\section{KESIMPULAN}

Dilihat dari pola konsumsi beras tingkat rumah tangga di Kota Bandar Lampung, maka jenis beras yang paling banyak dikonsumsi rumah tangga adalah beras IR64 diikuti beras asalan, pandan wangi dan Rojolele. Frekuensi konsumsi beras rumah tangga rata-rata adalah tiga kali per hari. Kualitas beras yang banyak dikonsumsi rumah tangga adalah beras super. Sebagian besar alasan rumah tangga mengkonsumsi beras adalah karena kebiasaan. Jumlah beras yang dikonsumsi rata-rata adalah 25,31 $\mathrm{kg} / \mathrm{rumah}$ tangga/bulan atau 6,33 $\mathrm{kg} / \mathrm{kapita} /$ bulan. Faktor-faktor yang berpengaruh nyata terhadap permintaan beras tingkat rumah tangga di Kota Bandar Lampung adalah harga roti dengan koefisien regresi sebesar $-0,1681$, harga ayam dengan nilai koefisien regresi sebesar 0,7199 dan jumlah anggota rumah tangga denga nilai koefisien regresi sebesar 1,0451.

\section{DAFTAR PUSTAKA}

Anggraini SL, Prasmatiwi FE, dan Nurmayasari I. 2016. Permintaan dan kepuasan rumah tangga dalam mengkonsumsi beras siger di Kota Bandar Lampung. Jurnal Ilmu Ilmu Agribisnis, $\quad 4(1)$ : 76-85. http://jurnal.fp.unila.ac.id/index.php/JIA/articl e/view/1217/1114. [5 Mei 2020]

Ariesman LS, Prasmatiwi FE, dan Indriani Y. 2015. Permintaan dan kepuasan konsumen rumah tangga dalam permintaan kecap manis di Bandar Lampung. Jurnal Ilmu Ilmu Agribisnis, 3(2) : 211-218. http://jurnal.fp.unila.ac.id/index.php/JIA/articl e/view/1041/946. [1Juli 2020]

Azhar MR, Zakaria WA, dan Adawiyah R. 2019. Pola konsumsi tahu tempe pada keluarga prasejahtera di Kelurahan way lunik Kecamatan Panjang Bandar Lampung. Jurnal Ilmu Ilmu Agribisnis 7(2):165-171. http://jurnal.fp.unila.ac.id/

index.php/JIA/article/view/3377/2578. [2 Juli 2020]

BPS [Badan Pusat Statistik]. 2017. Kajian Konsumsi Bahan Pokok. Badan Pusat Statistik. www.bps.go.id. [30 Januari 2018].

BPS [Badan Pusat Statistik] Provinsi Lampung. 2015. Data Kebutuhan Beras Nasional 2015. www.bps.go.id. [30 Januari 2018].

2017. Data Produksi Padi, Jagung, dan Kedelai Provinsi Lampung Tahun 2015. www.bps.go.id. [30 Januari 2018].

Bangun HP, Hutajalu AT, dan Salmiah. 2013. Analisis pola konsumsi pangan dan tingkat konsumsi eras di desa Sentra produksi padi (Studi Kasus: desa dua Ramunia, Kecamatan Beringin, Kabupaten Deli Serdang). Journal On Social Economic Of Agriculture And Agribusiness, 2 (7) :1-7. http://repository .usuac.id/bitstream/handle/123456789 [5 Mei 2020].

Deviana I, Kusrini N, Suyatno A. 2014. Analisis permintaan rumah tangga terhadap beras 
produksi Kabupaten Kubu Raya. Jurnal Social Economic of Agriculture, 3 (2): 3-67. http://dx.doi.org/10.26418/j.sea.v3i2. 9056. [ 3 mei 2020 ].

Ghozali I. 2007. Aplikasi Analisis Multivariate Dengan Program SPSS. Cetakan IV. Badan Penerbit Universitas Diponegoro. Semarang.

Imelda. 2016. Karakteristik dan Pola Konsumsi Pangan Rumah Tangga Masyarakat Kota Pontianak. Ethos (Jurnal Penelitian dan Pengabdian Masyarakat), 6 (2): 250-259. https://doi.org/10.29313/ethos.v6i2.3441. 31 Januari 2018 ].

Harianto dan Susila DAB. 2009. Permintaan Beras Rumahtangga Petani Padi. Jurnal Agribisnis dan Ekonomi Pertanian, 3(2): 90103. https://journal.ipb.ac.id/index. php/ jurnal agribisnis/article/view/17086.[29 April 2020].

Hendaris TW, Zakaria WA, dan Kasymir E. 2013. Pola konsumsi dan atribut-atribut beras siger yang diinginkan rumah tangga di Kecamatan Natar Kabupaten Lampung
Selatan. Jurnal Ilmu Ilmu Agribisnis, 1 (2): 232-237. http:// jurnal. fp.unila.ac.id/index.php/JIA/issue/view/69. [3 Juli 2020].

Hessie R. 2009. Analisis produksi dan konsumsi beras dalam negeri serta implikasinya terhadap swasembada beras di Indonesia. Skripsi. Departemen Ekonomi Sumberdaya dan Lingkungan, Fakultas Ekonomi dan Manajemen, IPB. Bogor.

Nopirin. 1994. Pengantar Ilmu Ekonomi Mikro dan Makro. BPFE Yogyakarta. Yogyakarta.

Prasmatiwi FE, Listiana I, dan Rosanti N. 2014. Konsumsi dan permintaan pangan rumah tangga petani padi di Kabupaten Lampung Tengah. Jurnal Ilmiah Gema Ekonomi, 4 (2): 529-540. https://e-jurnal. stieprasetiyamandiri. ac.id/index.php/gem/article/view/112 [ 4 Mei 2020 ].

Santoso, 2004. Kesehatan dan Gizi. Cetakan II. Rineka Cipta. Jakarta.

Sugiarto. 2001. Teknik Sampling. PT. Gramedia Pustaka Utama. Jakarta. 